\section{TOVÁBB NÖVEKEDETT 2018-BAN A MEZŐGAZDASÁGI DÍJTÁMOGATOTT BIZTOSÍTÁSOK ÁLLOMÁNYDÍJA}

\section{Gazdag Gyula (biztositási fötanácsos)}

\section{ÖSSZEFOGLALÓ}

Hazánkban 2012-ben új, kétpilléres mezőgazdasági kockázatkezelési rendszer került bevezetésre, melynek 2. pillérét a biztosítási díjtámogatás alkotja, ami a mezőgazdasági termelők és a biztosítók számára egyaránt ösztönző hatású volt. Jelen írás ezen termékcsoport legfrissebb aktualitásairól ad összefoglalót.

\section{SUMMARY}

In 2012 a new two-pillar risk management scheme has been introduced in the agricultural sector. Under the second pillar the crop and plan insurance enjoy premium-subvention provided by the government. This subsidy had a motivating impact both on farmers and insurance companies. Present article is summarizing the recent developments of this product line.

\section{Kulcsszavak: mezőgazdasági biztosítás}

Keywords: agricultural insurance

JEL: G22, Q10

DOI: $10.18530 /$ BK.2019.2.96

http://dx.doi.org/10.18530/BK.2019.2.96
Magyarországon az uniós csatlakozást követően 2012-től részesülhetnek mezőgazdasági biztosítási díjtámogatásban a termelök. Ennek lehetőségét az új kockázatkezelési rendszer bevezetése tette lehetővé, melynek keretében kialakításra került a mezőgazdasági kockázatkezelési rendszer II. pilléreként a díjtámogatott növénybiztosítási konstrukció.

A díjtámogatott biztosítások bevezetését követő időszak alatt a rendszer jogszabályi alapja is változott: 2014-ig az Európai Mezőgazdasági Garancia Alap szabályai alapján finanszírozott programként működött, 2015-ben átmenetileg nemzeti támogatásként, 2016-tól pedig a Vidékfejlesztési Program keretében igényelhető a díjtámogatás. Azonban nemcsak a jogszabályi keret módosult, hanem az eltelt időszak működési tapasztalatai alapján a díjtámogatott konstrukciók tartalmát is folyamatosan fejlesztette a tárca annak érdekében, hogy a termelők igényeinek minél inkább megfelelővé váljon e népszerü támogatási forma.

A biztosítási díjtámogatás 2012-es bevezetése óta a fejlődés töretlen, hiszen évről évre folyamatosan nőtt a díjtámogatott biztosítást kötő termelők és az igénybe vett módozatok száma, valamint a biztosítások díjállománya. A 2016. évi kiugróan magas, 35 százalékos állománydíj-növekedés megismételhetetlen volt, azonban, ha kisebb mértékben ugyan, de folyamatos díjnövekedés tapasztalható az elmúlt két év adatai alapján is.

A díjtámogatott növénybiztosítások állománydíjának fejlődését az 1. táblázat szemlélteti:

1. táblázat: Díjtámogatott növénybiztosítások állománydíjának alakulása

\begin{tabular}{|l|c|c|c|}
\hline Év & Módozat (db) & Díjállomány (millió Ft) \\
\hline 2012 & & 1896 & 1467 \\
\hline 2013 & & 7741 & 4018 \\
\hline 2014 & 13088 & 5679 \\
\hline 2015 & 16318 & 5752 \\
\hline 2016 & & 20694 & 7784 \\
\hline 2017 & 26785 & 9839 \\
\hline 2018 & 32728 & 10190 \\
\hline
\end{tabular}

Forrás: MABISZ, MÁK 2018

Az évről évre tapasztalható díjállomány-növekedés a rendszerben részt vevők közös munkájának sikerét jelzi, melynek eredményeként egyre többen foglalkoznak díjtámogatott biztosításokkal. Míg 2012-ben mindössze 3 piaci biztosító kínált díjtámogatott mezőgazdasági biztosításokat, addig 2018-ban már 4 piaci biztosító és 7 nonprofit biztosítóegyesület vett részt az értékesítésben. A csatlakozási lehetőség továbbra is nyitott a többi biztosító, nonprofit biztosítóegyesület számára, hiszen mindannyiunk közös célja, hogy a termelök minél szélesebb köréhez eljussanak a díjtámogatott biztosítások. 


\section{A díjtámogatott biztosítások föbb jellemzői}

A rendszer indulása óta három növénybiztosítási konstrukció részesülhet támogatásban, melyeknek lényeges elemei a következők:

- Az „A” típusú biztosítás egyfajta csomagbiztosítás, ami azt jelenti, hogy valamennyi veszélynemre együttesen köthető. A konstrukció kockázatvállalása a jégesőkár, az aszálykár, a mezőgazdasági árvízkár, a téli fagykár, a tavaszi fagykár, az őszi fagykár, felhöszakadáskár, a viharkár és a tüzkár térítésére terjed ki, a biztosítható növények pedig a legnagyobb vetésterületen termesztett szántóföldi növények, mint a búza, a kukorica, az őszi káposztarepce, a triticale, a rozs, az árpa és a napraforgó, valamint a hazánkban leggyakoribb ültetvények (szőlő, alma és körte).

- A „B” típusú biztosítás keretében a jégesőkár, a téli fagykár, a viharkár és a tűzkár biztosítható, mely kockázatok külön-külön is választhatók. Ezzel a termékkel az „A” csomagban nem szereplő ültetvények, illetve a fontosabb zöldségnövények biztosíthatók. - A „C” típusú biztosítás kockázati köre megegyezik az „A” termékével, azzal a különbséggel, hogy a termelő kiválaszthatja, hogy azok közül mely kockázatokra kíván biztosítást kötni. A „C” típusú biztosítás a kockázatkezelési szempontból releváns bármely növénykultúrára megköthető, ezek pontos listáját az Egységes Kérelem (EK) benyújtásához a kifizető ügynökség honlapján közzétett Hasznosítási Kódok tartalmazzák.

Az egyes díjtámogatott biztosítási konstrukciók (módozatok) igénybevétele eltérő volt 2018-ban is, megoszlásuk 2018-ban az alábbi volt (2. táblázat):

2. táblázat: Díjtámogatott biztosítások módozatonkénti igénybevétele

\begin{tabular}{|l|c|c|}
\hline Módozat & Darabszám $(\mathbf{d b})$ & Díjállomány (millió Ft) \\
\hline "A" típus & 5240 & 4297 \\
\hline „B" típus & 17529 & 3856 \\
\hline "C" típus & 9959 & 2037 \\
\hline Összesen & 32728 & 10190 \\
\hline
\end{tabular}

Forrás: MABISZ, MÁK 2018

Az egyes biztosítási típusok eltérő díjállományának oka egyrészt a termelők biztosítási szokásaiban, másrészt az egyes konstrukciókra vonatkozó eltérő támogatási intenzitásban keresendő. Amennyiben elegendő forrás áll rendelkezésre, a megkötött mezőgazdasági biztosítás díjához 65 százalékos támogatásban részesülhetnek a termelők. A rendelkezésre álló éves forrást meghaladó támogatási igény esetén azonban visszaosztás válik szükségessé, és a támogatási intenzitás csökkentése az egyes biztosítási típusoknál eltérően történik.
Szükséges továbbá megemlíteni, hogy a termelői igények reális megítélése nem könnyü feladat, illetve a fejlesztések várható hatását nehéz megjósolni. Ugyanis a termelők számára nem egyedüli szempont a díjtámogatás mértéke, hanem meghatározó a biztosítási tapasztalatuk és termelési gyakorlatuk során az általuk termesztett adott növény reagálása a kockázatokra, valamint nem elhanyagolható szempont a biztosítási díj mértéke sem. Ugyanis hiába magasabb a támogatási intenzitás az „A” csomagban biztosított növények esetében, a termelők több esetben mégis inkább az alacsonyabb támogatási intenzitású, ugyanakkor alacsonyabb díjvolumenű „C” csomagot részesítették előnyben. Ezt mutatják az AKI 2017-re közzétett adatai, melyek szerint borszőlő esetében az „A” csomag keretében lefedett biztosított terület a borszőlöültetvény területének 1,5 százaléka volt, míg a „C” csomaggal lefedett terület esetében ennél lényegesen magasabb, 3,7 százalék volt a biztosítási lefedettség. Az együttes területi lefedettség pedig elérte az 5,2 százalékot.

\section{A termelöi igények reális megítélése nem könnyü feladat.}

Az egyes ültetvénykultúrák adatai alapján megfigyelhető továbbá, hogy hiába magasabb például a borszőlö támogatási intenzitása, mint a kajszibaracké, az együttes területi lefedettség a kajszibarack esetében mégis 15 százalék, ami közel háromszorosa a borszőlő lefedettségének. Ez az eltérés is főként a termelők biztosítási szokásaival magyarázható.

\section{A biztosítási díjtámogatás igénylése}

2016-tól a mezőgazdasági biztosítási díjtámogatás a Vidékfejlesztési Program (VP) keretében került meghirdetésre, melynek következtében kismértékben módosultak a támogatási feltételek, amelyeket a Pályázati Felhívás, illetve a VP Irányító Hatóságának közleményei szabályoznak. Az új rendszer kialakításakor az a cél vezérelte a döntéshozókat, hogy a lehető legkevesebb változtatással kerüljön át a biztosítási díjtámogatás a VP intézkedései közé, és a már megszokott eljárások, támogatási feltételek megmaradjanak.

Az Egységes Kérelem (EK) felületen beadott támogatási kérelem egyúttal kifizetési igénylésnek is minősül. A támogatási kérelmek benyújtására a tárgyévi egységes kérelemről szóló rendeletben meghatározott, az Egységes Kérelem benyújtására nyitva álló időszakban van lehetőség.

A biztosítási díjámogatási igény EK-n történő jelölésén kívül a termelőknek a támogatás igényléséhez mindössze annyit kell tenniük, hogy megkötik a jogosultsági feltételeknek megfelelő biztosítási szerződést, és megfizetik a biztosítási díjat. Biztosítási díjtámogatás ugyanis csak a ténylegesen megfizetett biztosítási díj alapján nyújtható.

A jogosultsági feltételek ellenőrzéséhez szükséges adatokat (szerződés adatai, díj igazolása) a biztosító küldi meg a kifizető ügynökség részére. Az ellenőrzéseket követően a VP Irányító Hatóság a mezőgazdasági biztosítás díjához nyújtott támogatásról Támogatói Okiratot állít ki, amely tartalmazza a támogatás összegét, valamint a támogatás intenzitását. 
A VP-ben a 17.1.1 számú, a „Mezőgazdasági biztosítások díjához nyújtott támogatás” című intézkedés keretösszege 2020-ig 29,6 milliárd forintban került megállapításra. Ez a keretösszeg lehetővé tette, hogy a biztosítási díjtámogatás éves forrása 2018-ban 1 milliárd forinttal bővüljön, és így 2018-ban (a 2018. augusztus 13-án megjelent Pályázati Felhívás módosítás alapján) már 5 milliárd forint áll rendelkezésre a termelői igények teljesítésére.

\section{A díjtámogatás forrásának visszaosztása}

A visszaosztás számítása a „C” típusú biztosítások támogatási intenzitásának csökkentésével kezdődik, majd ezt követi a „B” típusú biztosítások díjtámogatásának visszaosztása, és az „A” típusú biztosítások támogatása csak utolsóként kerül csökkentésre. Az „A” típusú biztosítás a magasabb biztosítási díj miatt előnyt élvez, mivel ez a csomagbiztosítás több kockázat ellen véd, és ezért célszerű jobban támogatni. Amennyiben a forrás még így sem elegendő a díjtámogatás kifizetésére, mindhárom biztosítási típus támogatási összegének arányos csökkentésére kerül sor.

A visszaosztás alkalmazásával garantálható, hogy valamenynyi jogosult termelö támogatáshoz jusson, ugyanakkor az intézkedés forrása is tervezhetővé válik.

A díjtámogatási rendszer bevezetésétől kezdve azért került így kialakításra, mert a visszaosztás alkalmazásával garantálható, hogy valamennyi jogosult termelő támogatáshoz jusson, ugyanakkor az intézkedés forrása is tervezhetővé válik. A korábbi évekhez képest lényeges változást jelent azonban, hogy 2016-tól a dítámogatásnak garantált minimális szintje is van. A „B” és „C” típusú biztositások esetében ez az alsó limit 30, az „A” típusú biztosításoknál pedig 41,25 százalék. Kismértékben módosult a visszaosztás számításának menete is, ezzel a „C” típusú biztosítások támogatásintenzitása kedvezőbbé vált. A támogatási intenzitás csökkentésének sorrendjét és a 2016-tól bevezetett módosításokat a 3. táblázat szemlélteti:

3. táblázat: A támogatási intenzitás csökkenésének sorrendje

\begin{tabular}{|l|c|c|}
\hline $\begin{array}{l}\text { A támogatásintenzitás } \\
\text { csökkentésének sorrendje }\end{array}$ & $\mathbf{2 0 1 2 - 2 0 1 5}$ & 2016-tól (VP)) \\
\hline 1. „C” típusú biztosítások esetében & $30 \%$-ig & $40 \%$-ig \\
\hline 2. „B” típusú biztositások esetében & $40 \%$-ig & $40 \%$-ig \\
\hline 32. „B" típusú biztosítások esetében & $55 \%$-ig & $55 \%$-ig \\
\hline 4. mindhárom típus esetén arányosan & $\begin{array}{c}\text { nincs alsó } \\
\text { korlát }\end{array}$ & „A” típus esetén 41,25\%-ig, \\
\hline
\end{tabular}

Forrás: saját szerkesztes
Lényeges változás tehát, hogy a „C” típusú biztosítások támogatási intenzitása első körben nem 30, hanem csak 40 százalékig csökken. Ezt az indokolta, hogy a szántóföldi növények biztosítása gyakran integrátorokon keresztül történik, akár 20-30 százalékkal alacsonyabb díjjal, és a termelők számára így már nem volt elég vonzó a 30 százalékos dijtámogatás. A módosítás következtében - mivel az a legnagyobb vetésterületen termesztett növényeket érintette - a termelők szélesebb köre juthat a korábbiakhoz képest magasabb mértékű dijtámogatáshoz.

2018-ban közel 15000 termelő kötött díjtámogatott biztosítást, ami az előző évhez képest mintegy ezer termelővel történő bővülést jelentett, és a dijtámogatási rendszer bevezetése óta az állománydíj először haladta meg a 10 milliárd forintot. Mivel a támogatási igény ismét meghaladta a rendelkezésre álló forrást, az utóbbi négy évhez hasonlóan az elmúlt évben is visszaosztás vált szükségessé. A támogatás jogosultsági feltételeinek ellenőrzése és a kifizetés túlnyomó részben megtörtént, és 4,97 milliárd forint kifizetésre került. A még függőben lévő ügyek esetében az egyeztetések, pontosítások folyamatban vannak. A kifizető ügynökségtől származó információk alapján az „A” típusú biztosítást kötő termelők a biztosítási díj 65, míg a „B” és „C”típusú biztosítással rendelkező termelők a díj 40 százalékát kapják vissza támogatásként..

\section{Az elmúlt hét év támogatási intenzitását a 4. táblázat mutatja be:}

4. táblázat: Támogatások intenzitása módozatonként

\begin{tabular}{|l|c|c|c|}
\hline Év & „A” típusú biztosítás & „B” típusú biztosítás & „C” típusú biztosítás \\
\hline 2012 & $65 \%$ & $65 \%$ & $65 \%$ \\
\hline 2013 & $65 \%$ & $65 \%$ & $65 \%$ \\
\hline 2014 & $65 \%$ & $63 \%$ & $30 \%$ \\
\hline 2015 & $65 \%$ & $52 \%$ & $30 \%$ \\
\hline 2016 & $65 \%$ & $43 \%$ & $40 \%$ \\
\hline 2017 & $49 \%$ & $34 \%$ & $34 \%$ \\
\hline 2018 & $65 \%$ & $40 \%$ & $40 \%$ \\
\hline
\end{tabular}

Forrás: MÁK 2018.

\section{Fejlesztések, módosítások 2018-ban}

A támogatási program elmúlt időszakában bővült a biztosítható kockázatok köre, illetve módosult a biztosítható növények köre. A támogatás forrásösszegét a kezdeti 3 milliárd forintról sikerült 4 milliárdra emelni, majd a 2018-as évben ez 5 milliárd forintra nőtt, ez a leglényegesebb változás a korábbi évekhez képest. 2019-ben is ez az összeg kerül majd szétosztásra. 
A díjtámogatott biztosítások elterjedésének, népszerüségének az utóbbi években a forrás hiánya és a visszaosztás mértéke volt a hátráltatója, ezért 2018-ban a legfontosabb és egyúttal a rendszer működése tekintetében kifejezetten kedvező változás a forrásösszeg 1 milliárd forinttal történő növelése volt. Az előbbi táblázat alapján megfigyelhető, hogy 2017-ben első alkalommal vált szükségessé az „A”csomag dijtámogatásának csökkentése, és a termelők a 65 százalékos helyett csupán 49 százalékos támogatásban részesülhettek. A termelők érzékenyen reagáltak e változásra, amely abban nyilvánult meg, hogy 2018-ban az „A” csomag díjállománya közel ötszáz millió forinttal csökkent, és a termelők inkább az alacsonyabb díjú „B” csomagot vették igénybe. 2018-ban viszont az „A” csomag támogatási intenzitása ismét 65 százalékra nőtt, és 40 százalékra emelkedett a „B” és „C” csomag támogatási intenzitása is.

További módosítás, amely a Pályázati Felhívás 2018. 11. 14- én történt módosítását követően lépett hatályba, a biztosítási típusok egyszerüsítése, mely alapján

- $\quad$ az „A” csomag növényei kiegészítésre kerültek a csonthéjas gyümölcsökkel

- a „B” csomagban szerepel valamennyi ültetvény és zöldség, szántóföldi zöldség

- a „C” csomagba került valamennyi szántóföldi növény (az „A”-ban megjelölt szántóföldi növények mellett)

Szükséges megjegyezni, hogy a „B” és a „C” csomag növényei között nem lehetséges átfedés.

Az elmúlt évi változások a korábbi évek fejlesztéseihez hasonlóan a mezőgazdasági termelők érdekeit szolgálják, ezeket követően a termelők nagyobb összegű támogatásban részesülhetnek, illetve egyszerűbbé, valamint még átláthatóbbá vált számukra a biztosítási dijtámogatási rendszer.

\section{IRODALOMJEGYZÉK}

2011. évi CLXVIII. törvény a mezőgazdasági termelést érintő̉ időjárásiés más természeti kockázatok kezeléséről 143/2011.(XX1.23.) FM rendelet a mezógazdasaggi biztositás dijához nyujitott támogatás igénybevételi felteteleir

Vígiékfejlesztési Alapból (EMVA) nyúitandó vidékfejelestéśs témomentés a

Felhivás a mezőgazdasági biztositás dijához nyúitott támogatásról (VP3-17.1.1-16) 